\title{
Effect of Sulphur Fertilization on Grain Quality and Protein Composition of Durum Wheat (Triticum durum Desf.)
}

\author{
Marianna Pompa ${ }^{1}$, Marcella Michela Giuliani ${ }^{1}$, Luigia Giuzio ${ }^{1}$, \\ Anna Gagliardi ${ }^{1}$, Natale Di Fonzo ${ }^{2}$, Zina Flagella*1 \\ ${ }^{1}$ Dipartimento di Scienze Agroambientali, Chimica e Difesa Vegetale \\ Centro di Ricerca Interdipartimentale Bioagromed, Università di Foggia \\ Via Napoli 25, 71100 Foggia, Italy \\ ${ }^{2}$ CRA-CER - Centro di Ricerca per la Cerealicoltura \\ S.S. 16, km 675, 71100 Foggia, Italy
}

Received: 14 September 209. Accepted: 28 October 2009.

\begin{abstract}
The reduction of atmosphere emission of $\mathrm{SO}_{2}$ and the massive use of fertilizers high in nitrogen and phosphorus resulted in a decrease of the sulphur content in the soil. In durum wheat cultivation, sulphur supply plays a key role not only for plant growth, but also for grain quality. Sulphur is an essential macronutrient primarily used to synthesize methionine and cysteine and it is also involved in establishing protein structures by disulphide bonds. The aim of this study was to evaluate the effect of sulphur nutrition on grain quality and protein composition of durum wheat cultivars grown under water deficit conditions, typical of Mediterranean areas. To this purpose, in the 2003-2004 and 2004-2005 crop seasons a field trial was carried out by comparing two water regimes (irrigated and rainfed), two sulphur fertilizer levels and two durum wheat cultivars. Under our experimental conditions, an increase in protein and gluten content in the rainfed treatment and a positive effect of sulphur fertilization on quality parameters were observed. Few changes were observed in protein composition in response to sulphur fertilization.
\end{abstract}

Key-words: durum wheat, grain quality, protein composition, sulphur fertilization.

\section{Introduction}

Sulphur is an essential nutrient, both for plants and animals. With other macronutrients, nitrogen, phosphorus and potassium, it is considered vital for plant growth and development, for resistance to pests and environmental stresses and for crop yield and quality (Naeem and MacRitchie, 2003).

Plants mainly uptake sulphur as sulphate through root system and carry it to the leaves. By means of some enzymatic steps, sulphate is converted to nutritionally and functionally compounds, such as cysteine, methionine, several coenzymes, thioredoxins, sulpholipids and vita- mins (biotin, thiamine) and ferredoxin (Hell, 1997; Hell and Rennenberg, 1998; Saito, 2000). Moreover, sulphur is involved in the formation of sulphydryl (SH) and disulphide bonds (SS), important for stabilization of protein structures and partially responsible for the viscoelastic properties of wheat gluten. An environmental policy leading to reduce $\mathrm{SO}_{2}$ atmospheric emissions, the massive use of nitrogen and phosphorus fertilizers and the introduction of high yielding crop cultivars resulted in a decrease in the sulphur content in the soils. Several researches agree on the importance of sulphur as a limiting factor in wheat production and quality deterioration (Byers and Bolton, 1979; Moss

* Corresponding Author: Tel.: +39 0881 589220; Fax: +39 0881 589340. E-mail address: z.flagella@unifg.it 
et al., 1981, 1983; Wrigley et al., 1984; Castle and Randall, 1987; MacRitchie and Gupta, 1993; Zhao et al., 1999a, 1999b; Luo et al., 2000; Wooding et al., 2000a, 2000b; Wieser et al., 2004; Lerner et al., 2006).

Depending upon available sulphur levels, the wheat yield can increase from 0 to $42 \%$ (Islam et al., 1999; De Ruiter and Martin, 2001), usually obtaining the best response with sulphur application between 10 and $20 \mathrm{~kg} \mathrm{ha}^{-1}$ (McGrath et al., 1996), even though higher supplies of sulphur (49-60 $\mathrm{kg} \mathrm{ha}^{-1}$ ) have been reported for highly calcareous soils in India (Sakal et al., 1999, 2000). This variation in sulphur requirement is due to soil type, climate and cropping system (Zhao et al., 1999a). Several greenhouse and field studies reported that sulphur primarily affects the number of grains per spike indicating that sulphur deficiency increases the mortality of florets or reduces the initiation of florets (Archer, 1974; Islam et al., 1999). Other yield components such as number of tillers and thousand grain weight are less affected by sulphur availability unless the deficiency is severe. In crops with marginal sulphur deficiency, application of the element may actually decrease thousand grain weight and produce grain with smaller test weight (Zhao et al., 1997). Grain sulphur concentrations lower than $1.2 \mathrm{mg} \mathrm{g}^{-1}$ and a grain $\mathrm{N}: \mathrm{S}$ ratio higher than 17:1 appear to be critic values for sulphur deficiency with regard to yield (Randall et al., 1981). Instead maintaining a $\mathrm{N}: \mathrm{S}$ fertilizer ratio of 3:1 appears to be helpful in minimizing detrimental effects on quality.

Sulphur supply has also a strong influence on the quality of storage proteins in bread wheat (Triticum aestivum L.). Sulphur availability doesn't alter protein properties such as electrophoretic mobility, but only their relative amounts (Moss et al., 1981; Wrigley et al., 1980, 1984). Sulphur deficiency during plant growth results in an increase in the relative amounts of high molecular weight glutenin subunits (HMWGS) and $\omega$-gliadins (sulphur poor proteins) and in a decrease of low molecular weight glutenin subunits (LMW-GS) and $\alpha$-, $\beta$ - and $\gamma$-gliadins (sulphur rich proteins), leading to an increase of HMW/LMW-GS ratio. These changes modify some functional properties: dough becomes stronger with increased mixing times, less extensibility and reduced loaf volume (Moss et al.,
1981; Zhao et al., 1999a, b; Naeem and Mac Ritchie, 2003).

The knowledge of sulphur nutrition effect on grain yield, quality and protein composition are limited in durum wheat (Triticum durum Desf.). Lerner et al. (2006) reported a significant increase in grain protein content and SDS-sedimentation test following sulphur fertilization, although no changes in rheological parameters (farinograph energy level, farinograph tolerance and viscoelasticity of cooked pasta) were observed, presumably due to non-limiting conditions for sulphur availability. Nevertheless several authors suggested S-fertilizer supply even in regions not deficient in soil $\mathrm{S}$, especially under conditions of high $\mathrm{N}$, to ensure the synthesis of S-rich proteins and disulphide-bridge formation required for gluten (MacRitchie and Gupta, 1993; Shewry and Tatham, 1997; Wrigley et al., 1980; Lerner et al., 2006). In fact, it's well known that disulphide bonds (SS), formed between the sulphydryl (SH) groups of cysteine residues, play a key role in determining the structure and properties of wheat proteins (Frater et al., 1960; Shewry and Tatham, 1997). Monomeric gliadins form only intra-chain disulphide bonds and contribute mainly to viscosity of dough, while polymeric glutenins have both intra-chain and interchain disulphide bonds and contribute mainly to dough elasticity (Shewry and Tatham, 1997). Zhao et al. (1999a) reported a decrease of dough extensibility related to a reduction of the disulphide groups, probably due to a lower concentration of sulphur in wheat grain.

The aim of this study was to evaluate the effect of sulphur nutrition on yield quality and protein composition of durum wheat cultivars cultivated under different water regimes in a typically Mediterranean environment of South Italy.

\section{Materials and methods}

\section{Agronomic trial}

During 2003-2004 and 2004-2005 crop seasons a field trial was carried out at Cereal Research Centre - CRA-CER in Foggia, Italy $\left(41^{\circ} 28^{\prime} \mathrm{N}\right.$, $15^{\circ} 32^{\prime} \mathrm{E}$ and $75 \mathrm{~m}$ a.s.l.), on a clay loam soil (American Soil Survey modified method Giardini, 2002) whose chemical and physical characteristics are reported in Table 1. A splitplot experimental design with three replicates 
Table 1. Principal physical and chemical soil characteristics.

\begin{tabular}{lccr}
\hline Parameter & Measurement unit & $2003-2004$ & $2004-2005$ \\
\hline Sand & $\%$ & 37 & 33 \\
Lime & $\%$ & 33 & 37 \\
Clay & $\%$ & 30 & 30 \\
Total nitrogen & $\mathrm{g} \mathrm{kg}^{-1}$ & 1.1 & 1.4 \\
Assimilable phosphorus $\left(\mathrm{P}_{2} \mathrm{O}_{5}\right)$ & $\mathrm{mg} \mathrm{kg}^{-1}$ & 105 & 70 \\
Exchangeable potassium $\left(\mathrm{K}_{2} \mathrm{O}\right)$ & $\mathrm{mg} \mathrm{kg}^{-1}$ & 745 & 918 \\
Active limestone & $\mathrm{g} \mathrm{kg}^{-1}$ & 59 & 27 \\
Water pH & $\%$ & 8.6 & 8.15 \\
Organic matter & $\%$ mg kg-1.w. & 2.2 \\
Total sulphur & $\%$ d.w. & 156 & 230 \\
Field capacity (gravimetric analysis) & $\%$ d.w. & 34 & 32.5 \\
Permanent wilting point (-1,5 MPa) & & 13 & 14.5 \\
\hline
\end{tabular}

and three factors was carried out, with two water regimes (rainfed and irrigated) in main plots (spaced with an area of board), two sulphur fertilizer levels ( $\mathrm{S} 0$ and $\mathrm{S} 1$ corresponding to 0 and $90 \mathrm{~kg}$ sulphur ha- ${ }^{-1}$, respectively) in plots and two durum wheat cultivars (Creso and Simeto), chosen among the more cultivated ones in Italy (D'Egidio et al. 2004; Asciuto and Schimmenti 2006), in sub-plots. Each sub-plot was $20.4 \mathrm{~m}^{2}$.

The sowing dates were November $24^{\text {th }}$ and December $22^{\text {nd }}$ in 2003 and 2004, respectively, with a seed density of 350 seeds $\mathrm{m}^{-2}$ in both years. At sowing date, $92 \mathrm{~kg} \mathrm{ha}^{-1}$ of phosphorus fertilizer (as superphosphate) and $30 \mathrm{~kg} \mathrm{ha}^{-1}$ of nitrogen (as urea) were applied as basal dressing. During stem elongation $60 \mathrm{~kg} \mathrm{ha}^{-1}$ of nitrogen, as ammonium nitrate, were applied; sulphur fertilizer was added as elemental S (Grinver, $87 \%$ ) on March $16^{\text {th }}$ and April $10^{\text {th }}$ in the 2004 and 2005, respectively.

The irrigation treatment, in both years, consisted in bringing soil moisture up to field capacity, whenever the threshold of $50 \%$ of available soil water content was reached.

In Figure 1 ten-day maximum and minimum temperatures and rainfall for the two crop seasons are reported. As for temperatures, no differences were observed between the mean values of 2003-2004 and 2004-2005 climatic trends (max Temp. 19.7 vs 19.6; min Temp. 8.9 vs 9.0), being these values also in agreement with those reported for a period of twenty-year recorded in the same area $\left(\max\right.$ Temp. $18.7^{\circ} \mathrm{C}$; min Temp. $7.3{ }^{\circ} \mathrm{C}$, Troccoli et al., 2007).

With regard to rainfall, while no differences in the total amount of precipitations was observed between the two crop seasons $(453.7 \mathrm{~mm}$ and $471.6 \mathrm{~mm}$, in the first and the second year respectively), there was a different rainfall distribution. The 2003-2004 crop season was characterized by low rainfall before sowing date (18\% soil water content) and by intensive rainfall in December (about $170 \mathrm{~mm}$ ) and during grain filling period between May and June (about $120 \mathrm{~mm}$ ), so that a single water supply was necessary on May $17^{\text {th }}\left(504 \mathrm{~m}^{3} \mathrm{ha}^{-1}\right)$. Otherwise in 2004-2005 crop season an intense rain
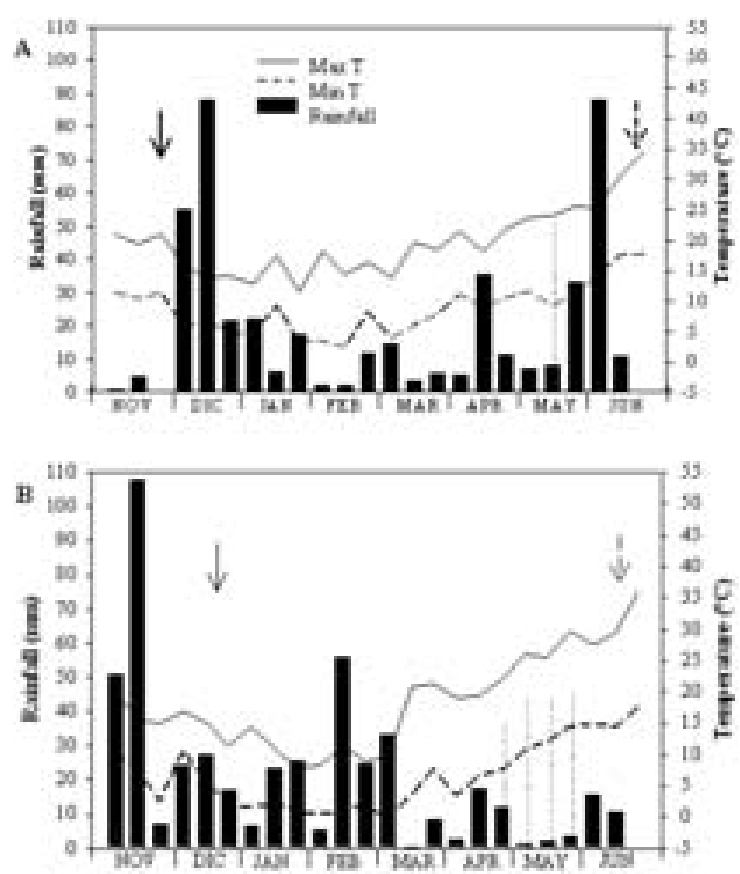

Figure 1. Ten-day maximum and minimum temperatures and rainfall in Foggia during 2003-2004 (A) and 20042005 (B) crop seasons. The amount of irrigation ( $\mathrm{mm}$ ) is indicated with dotted vertical line. The unbroken and the dotted arrows indicate the sowing and the physiological maturity dates, respectively. 
(166 mm) fell in November leading to a $36 \%$ soil water content at sowing, while the scarcity of rainfall $(11.2 \mathrm{~mm})$ that occurred during grain filling resulted in the application of four irrigation treatments for a total of $1,674 \mathrm{~m}^{3} \mathrm{ha}^{-1}$ of water from April to May.

In the first year crop growing cycle and grain filling period were longer compared to the second year (173 days vs 146 days for crop growing cycle and 45 days vs 36 days for grain filling period). Also degree days registered during growing cycle was higher in the first year $\left(2389.3{ }^{\circ} \mathrm{C}\right.$ vs $1788.7^{\circ} \mathrm{C}$ ). Evaporate (E) sum, obtained by class A pan evaporimeter, was $241 \mathrm{~mm}$ in the first year and $275 \mathrm{~mm}$ in the second one.

The crop water deficit, calculated as ratio between effective rain and crop evapotranspiration $(\mathrm{Etc}=\mathrm{E} \cdot \mathrm{Kp} \cdot \mathrm{Kc}$, where $\mathrm{Kp}=$ pan coefficient (0.75) and $\mathrm{Kc}=$ crop coefficient (ranging from 0.7 to 1.15 ), was lower in the first crop season than in the second one ( $14.7 \%$ vs $34.8 \%)$.

Grain samples were harvested at the physiological maturity on June $21^{\text {st }}$ and June $14^{\text {th }}$ in 2004 and 2005, respectively. Then, grain yield ( $\mathrm{t}$ ha $^{-1}$, standardized at $13 \%$ grain humidity), its main components (thousand grain weight $(\mathrm{g})$ and kernels number $\mathrm{m}^{-2}$ ) and some quality parameters (protein and gluten content, SDS sedimentation index, gluten index and yellow index), were evaluated on samples collected in triplicate on the sub-plot area.

\section{Grain quality parameters}

Grain nitrogen concentration was determined following the standard Kjeldhal method; percentage of protein content was calculated multiplying Kjeldhal nitrogen by 5.7 and was expressed on a dry weight basis. Gluten content (\%) was determined by whole grain analyzer Infratec 1229 with NIT (near infrared radiation transmittance) technique. Sodium-dodecyl sulphate (SDS) sedimentation test, expressed in mm, was evaluated according to Dick and Quick (1983). Gluten index was calculated as ICC 155 standard method by Glutomatic 2200; yellow index, at last, was determined by Chroma-Meter CR-200 reflectance colorimeter (Minolta).

Gluten proteins two-dimensional (2D) electrophoresis analysis

Gluten proteins (gliadins and glutenins) were extracted according to Hurkman and Tanaka
(2004) and then, quantified using the Biureto assay with BSA (albumin bovine serum) as standard. Samples containing $200 \mu \mathrm{g}$ of protein were loaded on each IEF gel.

Immobiline $^{\mathrm{TM}}$ DryStrips pH 3-10 L, $13 \mathrm{~cm}$, were used to perform first dimension electrophoresis after rehydration with a buffer containing 8M Urea, 2\% Triton X-100, $0.28 \%$ DTT, 0.5\% IPG buffer 3-10 (Amersham Pharmacia Biotech) and Bromophenol-blu. The first dimension was performed using the IPGphor $^{\mathrm{TM}}$ Isoelectic Focusing System (Amersham Pharmacia Biotech) according the following steps: rehydration occurred in $12 \mathrm{~h}$ at $20^{\circ} \mathrm{C}$, isoelectric focusing performed at $500 \mathrm{~V}$ for $1 \mathrm{~h}, 1000 \mathrm{~V}$ for $1 \mathrm{~h}, 5000 \mathrm{~V}$ for $2 \mathrm{~h}$ and $8000 \mathrm{~V}$ for $4 \mathrm{~h}$, as reported in Ferrante et al. (2006).

The separation in the second dimension was carried out with an SE 600 apparatus (Hoefer $\left.^{\mathrm{TM}}\right)$. Strips were equilibrated and then, loaded on $18 \times 16 \mathrm{~cm}$ vertical polyacrylamide SDSPAGE gels (T 12\%, C 1.28\%), 1 mm thick. Separation was performed at $30 \mathrm{~mA}$ per gel at 10 ${ }^{\circ} \mathrm{C}$ and stopped after the tracking dye ran off the gel. Staining was performed according to Neuhoff et al. (1988) with destaining in tap water. A molecular weight marker $(10-200 \mathrm{kDa}$, Amersham) was added. Three replicates were performed for each grain sample. Protein spots were analyzed by ImageMaster 2D Platinum 6.0 software (Amersham). T-test analysis of spot volume were performed using JMP statistical software.

\section{Statistical analysis}

After testing variance homogeneity in the studied characters by Bartlett's test, data of the two years were analyzed together, using the ANOVA procedure of M-stat C statistical package (Crop Soil Sciences Department Michigan State University). The significant differences among the mean values were calculated following Tukey test (Steel et al., 1997). Principal component analysis (PCA) was performed only on technological variables using JMP statistical software, version 3.2.5, SAS Institute Inc., 1999. Data set consisted of 48 samples and 5 variables (protein content, gluten content, SDS sedimentation test, gluten index and yellow index). Among the 5 factors obtained by the system, the first two were chosen and subjected to variance analysis. 


\section{Results}

\section{Yield and quality parameters}

From variance analysis relative to yield and its components, the effect of year (A) and water regime (B) was highly significant for all characters, the effect of cultivar (D) highly significant on yield and thousand kernel weight, while sulphur level (C) didn't show any significant effect. As for the two way interactions only $A B$ and $A D$ showed a significant effect on the yield characters (Fig. 2). In particular, a general decrease in yield and kernel number $\mathrm{m}^{-2}$ in the second year was observed. Due to irrigation, a significant increase in yield and its components was observed only in the second year. In AD interaction cultivars were statistically different for yield and thousand kernel weight, respectively in the second and the first year, with Simeto showing the highest values than Creso.

As for the quality variables, the effect of year (A) and cultivar (D) was always significant, sulphur level (C) showed a significant effect on SDS sedimentation test, gluten content and gluten index, while water regime (B) only on SDS sedimentation test. The two way and three way interactions were always significant for most of the characters analyzed. Since also ABCD interaction showed a significant effect on some of the quality characters it was reported in Figure 3.

A general increase in all technological parameters was observed in the second year.

Sulphur supply showed a significant effect only in the second year; an increase in SDS sedimentation test values in Creso and Simeto and in gluten index values only in Creso was observed for S1 level in the irrigated treatment.

As for water regime, a significant effect was observed in both years but only for Creso. In the rainfed condition, in the first year, a decrease in gluten index was recorded in S1 lev$\mathrm{el}$; on the contrary, an increase in protein content, gluten content and gluten index in the second year was observed for S0 level.

No differences between the two cultivars were observed in the first year for main parameters. In the second year Creso generally showed higher protein and gluten content; on the contrary, Simeto showed higher values than Creso for gluten and yellow index.

Some of the quality characters were highly correlated each other. In particular, positive correlations between protein content and gluten content $\left(0.9^{* *}\right)$ and gluten index $\left(0.3^{*}\right)$ were observed. Also SDS-sedimentation test was highly correlated to gluten content and gluten index $\left(0.4^{* *}\right)$, while yellow index was positively correlated to protein content $\left(0.3^{*}\right)$ and gluten in$\operatorname{dex}\left(0.6^{* *}\right)$.

Due to the high correlations observed among quality parameters and in order to have a general view of quality response under the different environmental conditions, principal component analysis (PCA) was performed on all the quality characters evaluated. Among the 5 factors obtained by the system, the first two were responsible for $81 \%$ of the total variance (Tab.
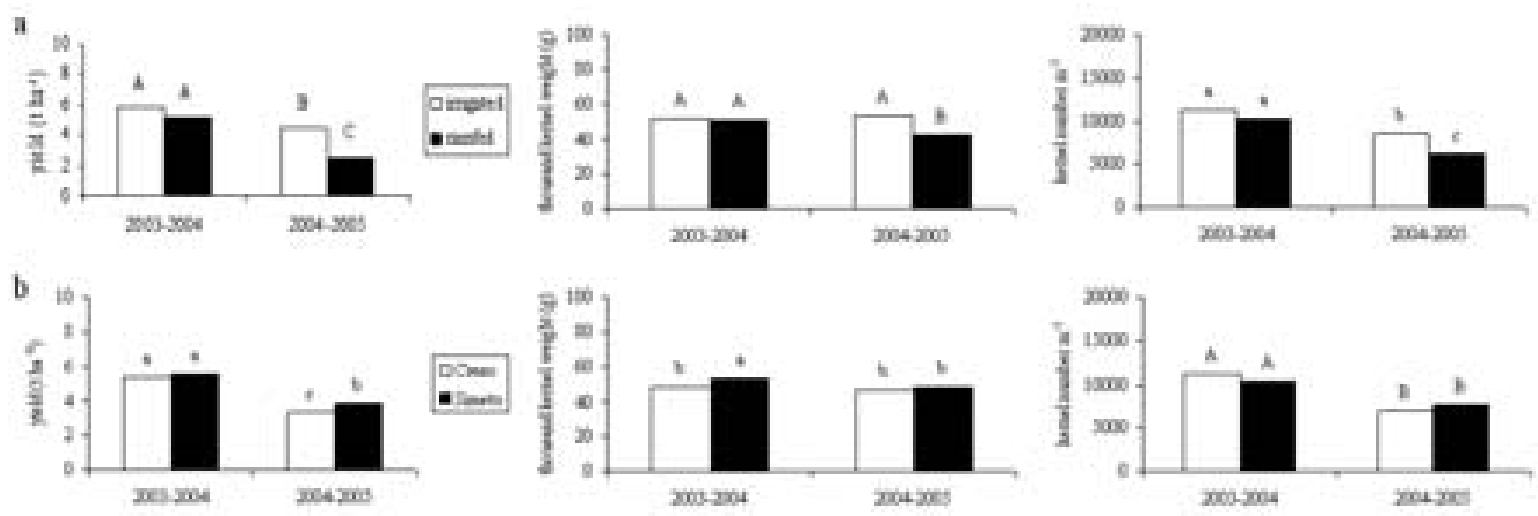

Figure 2. Effect of year $\mathrm{x}$ water regime $(\mathrm{AB})(\mathrm{a})$ and year $\mathrm{x}$ cultivar (AD) (b) interaction on yield parameters. Different letters indicate significant differences at 0.05 (small letters) and 0.01 (capital letters) $P$ levels according to Tukey test. 

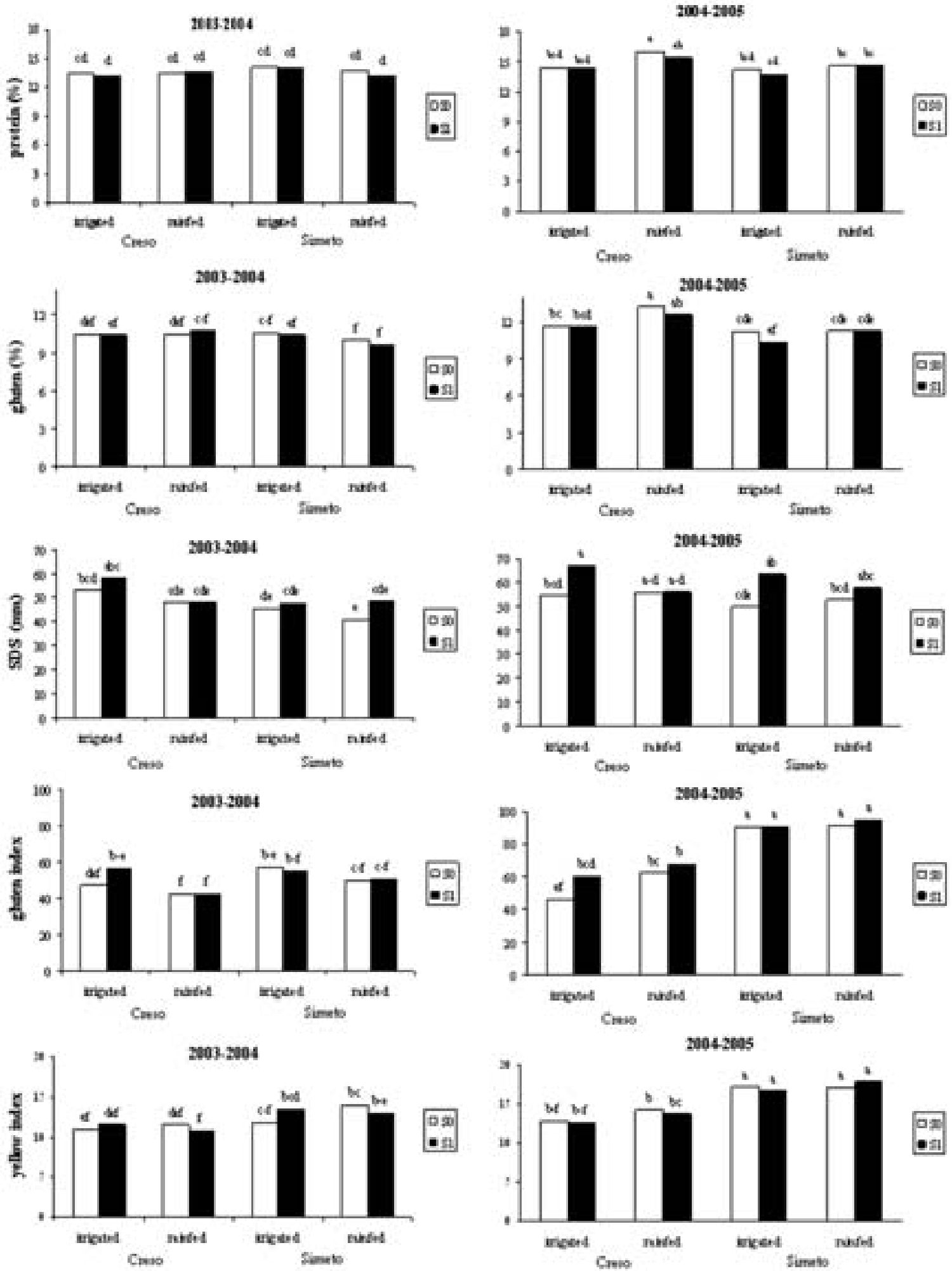

Figure 3. Effect of year $\mathrm{x}$ water regime $\mathrm{x}$ sulphur level $\mathrm{x}$ cultivar (ABCD) on quality parameters.

S0: $0 \mathrm{~kg} \mathrm{ha}^{-1}$ sulphur level; S1: $90 \mathrm{~kg} \mathrm{ha}^{-1}$ sulphur level. Different letters indicate significant differences at $0.05 P$ levels according to Tukey test. 
Table 2. Correlation matrix between original variables and first two PCA factors.

\begin{tabular}{lcc}
\hline & Factor 1 & Factor 2 \\
\hline Protein & 0.94 & 0.15 \\
Gluten & 0.98 & 0.05 \\
SDS & 0.44 & 0.34 \\
Gluten index & 0.14 & 0.96 \\
Yellow index & 0.12 & 0.95 \\
\% of total variance & 53 & 28 \\
\hline
\end{tabular}

2). In particular, factor 1, explaining $53 \%$ of total variance, was highly correlated to protein and gluten content, while factor 2, explaining $28 \%$ of total variance, was correlated to gluten and yellow index. SDS sedimentation test was equally correlated to both the factors. On the basis of this result we considered factor 1 as a "protein quantity" indicator and factor 2 as a "protein quality" indicator.

The year $\mathrm{x}$ water regime $\mathrm{x}$ sulphur level $\mathrm{x}$ cultivar (ABCD) interaction, derived from the ANOVA of the two factors, was graphically represented on a cartesian plane with factor 1 on $\mathrm{x}$-axis and factor 2 on y-axis (Fig. 4).

Figure 4 showed an increase in factor 1 (protein quantity) and factor 2 (protein quality) in the second year with respect to the first one. Differences among treatments (sulphur level and water regime) and between cultivars were observed only in the second year. Sulphur fer-

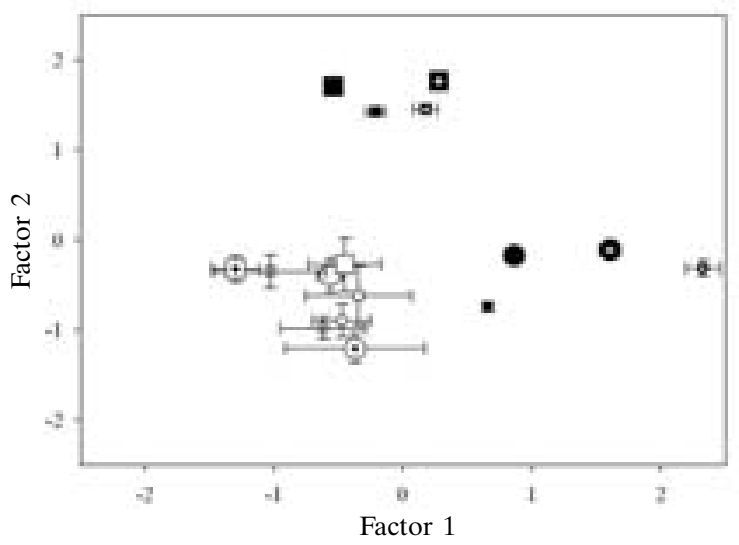

Figure 4. Year $\mathrm{x}$ water regime $\mathrm{x}$ sulphur level $\mathrm{x}$ cultivar (ABCD) interaction, derived from the variance analysis of the PCA two factors.

White symbols: 2003-2004 crop season; Black symbols: 20042005 crop season; Cross signed symbols: rainfed regime; No signed symbols: irrigated regime; Small symbols: $0 \mathrm{~kg} \mathrm{ha}^{-1}$ sulphur level; Large symbols: $90 \mathrm{~kg} \mathrm{ha}^{-1}$ sulphur level; Circle: Creso; Square: Simeto. tilization determined an increase in protein quality in Creso, mainly in the irrigated treatment, and a decrease in protein quantity in the rainfed one. Less noticeable differences were obtained between S levels in Simeto.

As for water regime in both cultivars, a significant increase in factor 1 in the rainfed treatment was observed. Only for Creso in the S0 level a slight increase in protein quality in the rainfed regime was also observed.

Finally as for cultivars performance, Simeto showed higher technological quality and Creso the higher protein content under all the experimental conditions.

\section{Protein composition}

Protein composition of storage proteins was evaluated by two-dimensional (2D)- electrophoresis analysis only on cultivar Creso that showed higher differences between sulphur levels and water regimes treatments in the second year (Fig. 5).

The 2-D gels were highly reproducible and showed well-resolved spots without streaking. On each gel about 150 spots were detected.

Between sulphur levels in irrigated treatment, 3 protein spots, all belonging to low molecular weight region, showed significant differences in spot volumes. In particular, spot 290 and 321 were more expressed in S0 level and spot 444 in S1 (Fig. 5 A and C). The correlation between gluten index and spot volume showed a high and negative coefficients for S0 more expressed spots $(-0.8 *$ and $-0.9 * *$ for 290 and 321, respectively) and high and positive correlation for S1 more expressed spot $\left(0.8^{*}\right.$ for 444$)$.

Between sulphur levels in rainfed treatment, no statistically significant differences were observed in protein spot volumes.

Only in S0 treatment significant differences in protein composition between water regimes were observed. In particular, 5 spots increased in rainfed regime: one belonging to high molecular weight region (77) and 4 belonging to low molecular weight region $(222,267,430,457)$. Also in irrigated treatment 5 spots significantly increased all belonging to low molecular weight region $(211,257,333,461,487)$ (Fig. 5 A and B). A high and positive correlation between gluten index and the volume of the spot more expressed in rainfed condition and high and negative correlation for the spot more expressed in irrigated treatment was observed. 


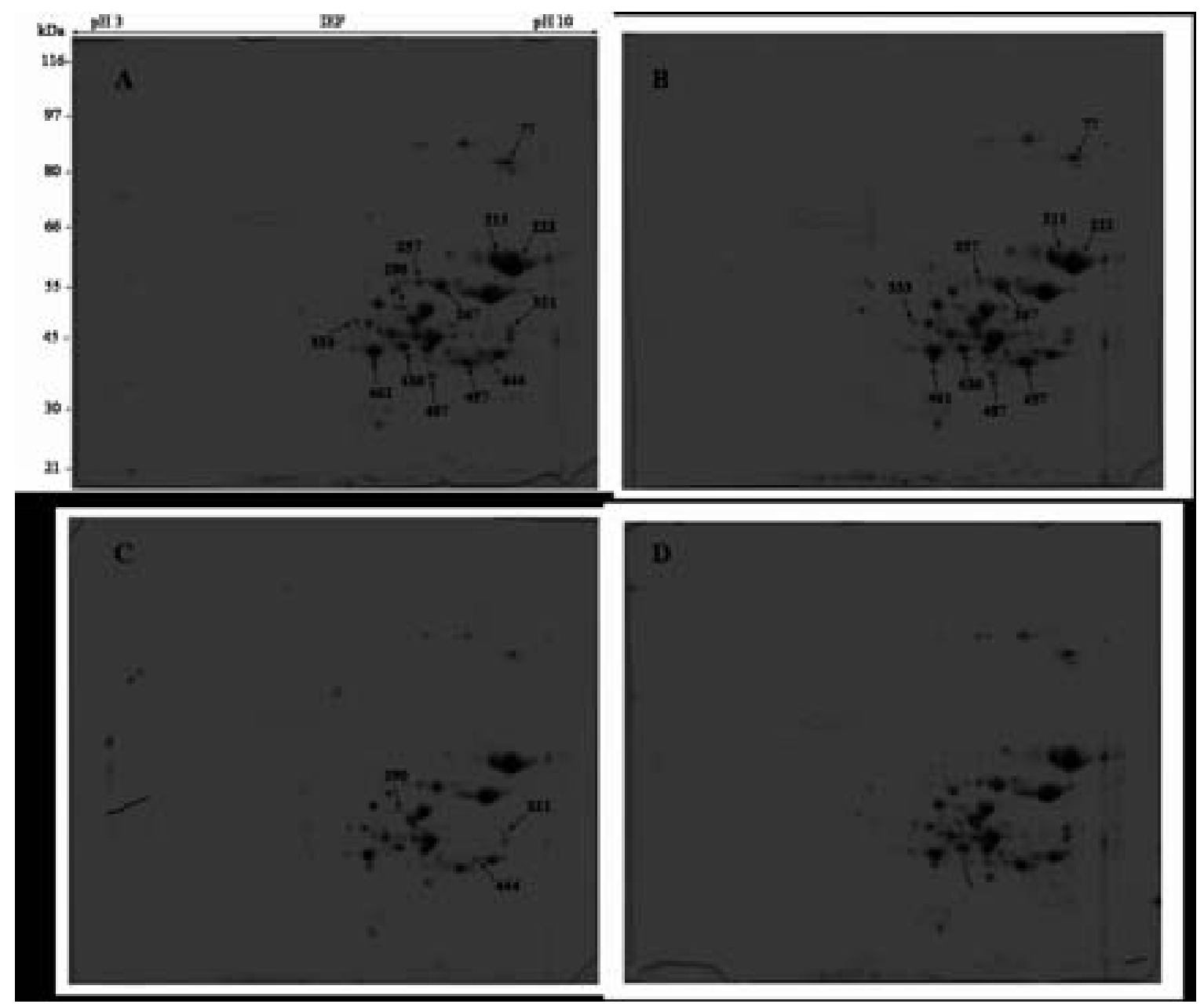

Figure 5. Gluten proteins two-dimensional (2D) gel electrophoresis of Creso.

A: S0 level in irrigated treatment; B: S0 level in rainfed treatment; C: S1 level in irrigated treatment; D: S1 level in rainfed treatment. Arrows indicate spots showing quantitative differences among studied thesis.

\section{Discussion}

As for yield and quality parameters, the two years were statistically different showing the first one the higher yield values and the second one the better technological performance (Fig. 2 and 3). The yield differences observed between the two years were probably due to the better rainfall distribution, the longer duration of crop cycle and grain filling and the lower crop water deficit occurred in the first year with respect to the second one (Fig. 1). The better grain quality observed in the second year might be probably due to water deficit occurred during grain filling. Moreover in this year also an effect of water regime was observed due to the higher crop water deficit recorded mainly in grain filling period (Fig. 1 and 3). In particular in rainfed condition a decrease in yield and its components (Fig. 2) and an increase in protein and gluten content were recorded. These results are in agreement with previous literature; in fact it is known that yield reduction that generally occurs under water stress conditions, is generally associated with an increase in protein content (Fig. 2 and 4) (Rao et al., 1993; Rharrabti et al., 2003a; Garrido-Lestache et al., 2005; Guttieri et al., 2005; Flagella, 2006).

Also a slight improvement in protein quality (Fig. 4) due to an increase in gluten index (Fig. 3) in the rainfed condition was observed only for 
Creso in the S0 level. This result is in accordance to Gooding et al. (2003), Labuschagne et al. (2006) and Ercoli et al. (2008), who reported that post-anthesis water stress, like that occurred in the rainfed condition of the second year (Fig. 1), improved grain quality. Also Rharrabti et al. (2003b) reported that total water input during grain filling negatively affects durum wheat grain quality. Furthermore Ottman et al. (2000) found that effects of irrigation frequency during grain filling on durum wheat grain quality are inconsistent.

As for S fertilization an affect on the technological parameters was observed only in the second year when later sulphur application might have improved its assimilation as observed by grain sulphur content $(0.14 \%$ vs $0.19 \%$ total S content in the first and in the second year, respectively, data not shown). In fact due to the later sowing date of the second year sulphur was supplied when temperature conditions might have been more favourable for sulphur assimilation (Fig. 1).

Sulphur fertilization positively affected SDS sedimentation test for both cultivars in irrigated treatment and gluten index only in Creso (Fig. 3 and 4). These results were in agreement with Zhao et al. (1999a) and Naeem and MacRitchie (2003), who reported an increase in technological performance following sulphur supply. In our experimental conditions no significant effects of $\mathrm{S}$ fertilization on protein and gluten content were observed. Contrasting are the results in literature on the effect of sulphur fertilization on protein content. In fact Randall et al. (1981) reported that an increase in applied $S$ may increase, decrease or have no effect on protein content, depending upon the grain S status and the $\mathrm{N}$ supply. Moreover, also Zhao et al. (1999a) and Naeem and MacRitchie (2003), showed that sulphur availability does not alter total protein content.

At last, as for cultivar performance Creso showed lower yield values consistent with a higher protein and gluten content, while Simeto showed the best technological performance (Fig. 4). These results are in agreement with Borghi et al. (1995), D'Egidio et al. (2000) and Flagella et al. (2002) who reported that cultivar Simeto, tested in different locations, shows a higher pasta-making quality.

As for storage protein composition, evaluat- ed by 2DE analysis on Creso in the second year, most of the over-expressed protein spots in rainfed regime and under sulphur fertilization, belong to low molecular weight region. A key role of LMW-GS for technological quality of durum wheat is reported in literature (D'Ovidio and Masci, 2004; Peña and Pfeiffer, 2005), while contrasting are the data on the role of HMW-GS (Porceddu et al., 1998; Ammar et al., 2000; Peña, 2000; Flagella, 2006). Few data are available in the literature on the effect of drought on durum wheat protein composition (Panozzo et al., 2001; Triboï et al., 2003; Hajheidari et al., 2007). Moreover as for sulphur fertilization, it's well known that it caused an increase of sulphur rich proteins, mainly low molecular weight proteins, like low molecular weight glutenin subunits (LMW-GS) and $\alpha-, \beta$ - and $\gamma$-gliadins (Zhao et al., 1999a and Naeem and MacRitchie, 2003). The improvement in technological quality might be due not only to changes in protein composition, but also to thiol-disulphide changes in wheat grain proteins. In fact Zhao et al. (1999b) and Tea et al. (2004) observed sulphydril groups/ disulphide bonds modifications following up sulphur fertilization.

In conclusion the results presented in this study showed that environmental conditions considerably affected yield, protein content and technological parameters. In particular, only in the second year, characterized by a higher crop water deficit, it was possible to observe differences between sulphur levels, water regimes and cultivars. Sulphur fertilization positively affected technological characters as gluten index and SDS sedimentation test in both cultivars, even if Creso showed more marked differences than Simeto.

As for water regime in rainfed condition a decrease in yield and its components and an increase in protein and gluten content were recorded. Only for Creso in the S0 level a slight increase in protein quality due to an increase of gluten index was observed.

As for cultivar performance Simeto showed the best technological values, but in Creso the effects of $\mathrm{S}$ level and water regime were more evident.

A preliminary study of gluten protein composition in Creso, performed by two-dimensional gel electrophoresis, revealed three differential expressed protein spots between S level, 
all belonging to low molecular weight region, and 10 differential expressed protein spots between irrigated and rainfed conditions, 1 belonging to high molecular weight region and 9 to low molecular weight region.

Further investigations are required to explain subunit identity by mass- spectrometry and to elucidate the role of the redox state of thiol groups in relation to durum wheat technological quality.

\section{Acknowledgements}

This work was supported by the Italian Ministry of University and Research (MIUR), project 'Miglioramento della qualità del frumento duro mediante la concimazione solfatica' (PRIN 2003), coordinated by prof. A. Masoni, local research leader prof. Z. Flagella.

\section{References}

Ammar K., Kronstad W.E., Morris C.F. 2000. Breadmaking quality of selected durum wheat genotypes and its relationship with high molecular weight glutenin subunits allelic variation and gluten protein polymeric composition. Cereal Chem., 77:230-236.

Archer J.M. 1974. A sand culture experiment to compare the effects of sulphur on five wheat cultivars (Triticum aestivum L.). Aust. J. Agric. Res., 25:369-380.

Asciuto A., Schimmenti E. 2006. Prezzi in ripresa per il grano duro. L'Inf. Agr., 35:28-32.

Borghi B., Corbellini M., Ciaffi M., Lafiandra D., De Stefanis E., Sgrulletta S., Boggini G., Di Fonzo N. 1995. Effect of heat shock during grain filling on grain quality of bread and durum wheat. Aust. J. Agric. Res., 46:1365-1380.

Byers M., Bolton J. 1979. Effects of nitrogen and sulphur fertilisers on yield, $\mathrm{N}$ and $\mathrm{S}$ content and amino acid composition of the grain of spring wheat . J. Sci. Food Agric., 30:251-263.

Castle S.L., Randall P.J. 1987. Effects of sulphur deficiency on the synthesis and accumulation of proteins in the developing wheat seed. Aust. J. Plant Physiol., 14:503-516.

D’Egidio M.G., Desiderio E., Cecchini C., Cantone M.T., Dottori A., Brogna G., Fornara M. 2000. Fertilizzazione azotata e qualità del frumento duro. Molini d'Italia, 8:39-44.

D'Egidio M.G., Di Fonzo N., Fares C., Palumbo M., Arcangeli A., Brandini R., Cecchini C., Colucci F., Gosparini E., Gulli S., Pucciarmati S., Schiavone M.G., Spina A., Virzì N. 2004. Frumento duro 2004, rese buone ma poche proteine. L'Inf. Agr., 36:47-52.

De Ruiter J.M., Martin R.J. 2001. Management of nitro- gen and sulphur fertilizers for improved bread wheat (Triticum aestivum) quality. New Zealand J. Crop and Hort. Sci., 29:287-299.

Dick J.W., Quick J.S.1983. A modified screening test for rapid estimation of gluten strength in early-generation durum wheat breeding lines. Cereal Chem., 60, 4:315-318.

D'Ovidio R., Masci S. 2004. The low molecular weight glutenin subunits of wheat gluten. J. Cereal Sci., 39:321-339.

Ercoli L., Lulli L., Mariotti M., Masoni A., Arduini I. 2008. Post-anthesis dry matter and nitrogen dynamics in durum wheat as affected by nitrogen supply and soil water availability Eur. J. Agron., 28:138-147.

Ferrante P., Masci S., D’Ovidio R., Lafiandra D., Volpi C., Mattei B. 2006. A proteomic approach to verify in vivo expression of a novel $\alpha$-gliadin containing an extra cysteine residue. Proteomics, 6:1908-1914.

Flagella Z., Campanile R.G., Pastore D., Di Fonzo N. 2002. New perspectives on near infrared reflectance and chlorophyll fluorescence analysis for testing durum wheat drought tolerance. Rec. Res. Dev. Plant Biol., 2:121-135.

Flagella Z. 2006. Qualità nutrizionale e tecnologica del frumento duro. Ital. J. Agron., 1:203-239.

Frater R., Hird F.J.R., Moss H.J., Yates J.R.A. 1960. A role for thiol and disulphide groups in determining the rheological properties of dough made from wheaten flour. Nature (London), 186:451-454.

Garrido-Lestache E., Lopez-Bellido R.J., Lopez-Bellido L. 2005. Durum wheat quality under Mediterranean conditions as affected by $\mathrm{N}$ rate, timing and splitting. $\mathrm{N}$ form and $\mathrm{S}$ fertilization. Eur. J. Agron., 23:265-278.

Giardini L. 2002. Agronomia Generale- ambientale e aziendale. Patron Editore.

Gooding M.J., Ellist R.H., Shewry P.R., Schofield J.D. 2003. Effects of restricted water availability and increased temperature on the grain filling, drying and quality of winter wheat. J. Cereal Sci., 37:295-309.

Guttieri M.J., McLean R., Stark J.C., Souza E. 2005. Managing irrigation and nitrogen fertility of hard spring wheats for optimum bread and noodle quality. Crop Sci., 45:2049-2059.

Hajheidari M., Eivazi A., Buchanan B.B., Wong J.H., Majidi I., Salekdeh G.H. 2007. Proteomics uncovers a role for redox in drought tolerance in wheat. J. Proteome Res., 6:1451-1460.

Hell R. 1997. Molecular biology of plant sulfur metabolism. Planta, 202:138-148.

Hell R., Rennenberg H. 1998. The plant sulfur cycle. In: Schung E. (ed): Sulphur in Agroecosystems, 135-137. Kluwer Academic Publishers, Dordrecht.

Hurkman W.J., Tanaka C.K. 2004. Improved methods for separation of wheat endosperm proteins and analysis by two-dimensional gel electrophoresis. J. Cereal Sci., 40:295-299.

Islam M.R., Islam M.S., Jahiruddin M, Hoque M.S. 1999. 
Effects of sulfur, zinc and boron on yield, yield components and nutrient uptake of wheat. Pak. J. Sci. Ind. Res., 42:137-140.

Labuschagne M.T., Meintjes G., Groenewald F.P.C. 2006. The influence of different nitrogen treatments on the size distribution of protein fractions in hard and soft wheat. J. Cereal Sci., 43:315-321.

Lerner S.E., Seghezzo M.L., Molfese E.R., Ponzio N.R., Cogliatti M., Rogers W.J. 2006. N- and S- fertilizer effects on grain composition, industrial quality and enduse in durum wheat. J. Cereal Sci., 44:2-11.

Luo C., Branlard G., Griffin W.B., McNeil D.L. 2000. The effect of nitrogen and sulphur fertilisation and their interaction with genotype on wheat glutenins and quality parameters. J. Cereal Sci., 31:185-194.

MacRitchie F., Gupta R.B. 1993. Functionality-composition relationships of wheat flour as a result of variation in sulfur availability. Aust. J. Agric. Res., 44:17671774.

McGrath S.P., Zhao F.J., Withers P.J.A. 1996. Development of sulfur deficiency in crops and its treatment. Proc. Fertilizer Society No. 379. The Fertilizer Society, Peterborough.

Moss H.J., Randall. P.J., Wrigley C.W. 1983. Alteration to grain, flour and dough quality in three wheat types with variation in soil sulphur supply. J. Cereal Sci., $1: 255-264$

Moss H.J., Wrigley C.W., MacRitchie F., Randall P.J. 1981. Sulfur and nitrogen fertilizer effects on wheat II. Influence on grain quality. Aust. J. Agric. Res., 32:213-226.

Naeem H.A., MacRitchie F. 2003. Effect of sulphur nutrition on agronomic and quality attributes of wheat. In: Abrol Y. P., Ahmad A. (eds): Sulphur in Plants, 305-322. Kluwer Academic Publishers, Dordrecht, The Netherlands.

Neuhoff V., Arold N., Taube D., Ehrhardt W. 1988. Improved staining of proteins in polyacrylamide gels including isoelectric focusing gels with clear background at nanogram sensitivity using Coomassie Brilliant Blue G-250 and R-250. Electrophoresis, 9:255262.

Ottman M.J., Doerge T.A., Martin E.C. 2000. Durum wheat quality as affected by nitrogen fertilization near anthesis and irrigation during grain filling. Agron. J., 92:1035-1041.

Panozzo J.F., Eagles H.A., Wootton M. 2001. Changes in protein composition during grain development in wheat. Aust. J. Agric. Res., 52:485-493.

Peña R.J. 2000. Durum wheat for pasta and bread-making. Comparison of methods used in breeding to determine gluten quality-related parameters. In: Royo C., Nachit M.M., Di Fonzo N., Araus J.L. (eds): Durum Wheat Improvement in the Mediterranean Region: New Challenges, Serie A: Séminaires Méditerranéennes No. 40, 423-430.Options Méditerranéennes, Zaragoza, España: Istituto Agronomico Mediterraneo di Zaragoza.
Peña R.J., Pfeiffer W.H. 2005. Breeding methodologies and strategies for durum wheat quality improvement. In: Royo C. et al. (eds): Durum wheat breeding. Current approaches and future strategies, 663-703. Binghamton, NY: Food Product Press.

Porceddu E., Turchetta T., Masci S., D’Ovidio R., Lafiandra D., Kasarda D.D., Impiglia A., Nachit M.M. 1998. Variation in endosperm protein composition and technological quality properties in durum wheat. Euphyt., 100:197-205.

Randall P.J., Spencer K., Freney J.R. 1981. Sulfur nitrogen fertilizer effects on wheat. I. Concentration of sulfur and nitrogen and the nitrogen to sulfur ratio in the grain in relation to yield response. Aust. J. Agric. Res., 32:203-212.

Rao A.C.S., Smith J.L., Jandhyala V.K., Papendick R.I., Parr J.F. 1993. Cultivar and climatic effects on protein content of soft white winter wheat. Agron. J., 85:1023-1028.

Rharrabti Y., Royo C., Villegas D., Aparicio N., Garcia del Moral L.F. 2003a. Durum wheat quality in Mediterranean environments I. Quality expression under different zones, latitudes and water regimes across Spain. Field Crops Res., 80:123-131.

Rharrabti Y., Villegas, D., Royo, C., Martos-Nuñez, V. and Garcia del Moral, L.F., 2003b. Durum wheat quality in Mediterranean environments. II. Influence of climatic variables and relationships between quality parameters. Field Crops Res., 80:133-140.

Saito K. 2000. Regulation of sulfate transport and synthesis of sulfur-containing amino acids. Curr. Opin. Plant Biol., 3:188-195.

Sakal R., Singh A.P., Sinha R.B., Bhogal N.S., Ismail M.D. 1999. Impact of sulphur fertilisation in sustaining the productivity of rice-wheat cropping system. Fert. News, 44:49-52.

Sakal R., Sinha R.B., Singh A.P., Bhogal N.S., Ismail M.D. 2000. Influence of sulphur on yield and mineral nutrition of crops in maize-wheat sequence. J. Indian Soc. Soil Sci., 48:325-329.

Shewry P., Tatham, A.S. 1997. Disulphide bonds in wheat gluten proteins. J. Cereal Sci., 25:2007-227.

Steel R.G.D., Torrie J.H., Dickey D.A. 1997. Principles and Procedure of Statistics: A Biometrical Approach. McGraw-Hill, New York.

Tea I., Genter T., Naulet N., Boyer V., Lummerzheim M., Kleiber D. 2004. Effect of foliar sulfur and nitrogen fertilization on wheat storage protein composition and dough mixing properties. Cereal Chem., 81:759766.

Triboï E., Matre P., Triboï-Blondel A.M. 2003. Environmentally-induce changes in protein composition in developing grains of wheat are related to changes in total protein content. J. Exp. Bot., 54:1731-1742.

Troccoli A., Colecchia S.A., Cattivelli L., Gallo A. 2007. Caratterizzazione agro-climatica del capoluogo dauno. Analisi della serie storica delle temperature e delle precipitazioni rilevate a Foggia dal 1955 al 2006. 
Wieser H., Gutser R., von Tucher S. 2004. Influence of sulphur fertilization on quantities and proportions of gluten protein types in wheat flour. J. Cereal Sci., 40:239-244.

Wooding A.R., Kavale S., Wilson A.J., Stoddard F.L. 2000a. Effects of nitrogen and sulphur fertilizer on commercial-scale wheat quality and mixing requirements. Cereal Chem., 77:791-797.

Wooding A.R., Kavale S., Wilson A.J., Stoddard F.L. 2000b. Effects of nitrogen and sulphur fertilizer on protein composition, mixing requirements and dough strength of four wheat cultivars. Cereal Chem., 77:798-780.

Wrigley C.W., duCros D.L., Downie P.G., Archer M.J., Roxburg C.M. 1980. The sulfur content of wheat-endosperm proteins and its relevance to grain quality. Aust. J. Plant Physiol., 7:755-766.

Wrigley C.W., duCros D.L., Fullington J.G., Kasarda
D.D. 1984. Changes in polypeptide composition and grain quality due to sulphur deficiency in wheat. J. Cereal Sci., 2:15-24.

Zhao F.J., Hawkesford M.J., McGrath S.P. 1999a. Sulphur assimilation and effects on yield and quality of wheat. J. Cereal Sci., 30:1-17.

Zhao F.J., Hawkesford M.J., Warrilow A.G.S., McGrath S.P., Clarkson D.T. 1997. Diagnosis of sulphur deficiency in wheat. In: Cram W.J., de Kok L.J., Stulen I., Brunold C.H., Rennenberg H. (eds): Sulfur Metabolism in Higher Plants: Molecular, Ecophysiological and Nutritional Aspects, 349-351. Backhuys Publishers, Leiden.

Zhao F.J., Salmon S.E., Withers P.J.A., Monaghan J.M., Evans E.J., Shewry P.R., McGrath S.P. 1999b. Variation in breadmaking quality and rheological properties of wheat in relation to sulfur nutrition under field conditions. J. Cereal Sci., 30:19-31. 